\title{
Dissolved organic carbon transformations and microbial community response to variations in recharge waters in a shallow carbonate aquifer
}

\author{
Katherine J. Cooper • Fiona F. Whitaker • Alexandre M. Anesio • \\ Miranda Naish • Darren M. Reynolds • Emma L. Evans
}

Received: 5 March 2015/Accepted: 18 June 2016/Published online: 29 July 2016

(C) The Author(s) 2016. This article is published with open access at Springerlink.com

\begin{abstract}
In carbonate aquifers, dissolved organic carbon from the surface drives heterotrophic metabolism, generating $\mathrm{CO}_{2}$ in the subsurface. Although this has been a proposed mechanism for enhanced dissolution at the water table, respiration rates and their controlling factors have not been widely evaluated. This study investigates the composition and concentration of dissolved organic carbon (DOC) reaching the water table from different recharge pathways on a subtropical carbonate island using a combination of DOC concentration measurements, fluorescence and absorption characterisation. In addition, direct measurements of the microbial response to the differing water types were made. Interactions of rainfall with the vegetation, via throughfall and stemflow, increase the concentration of DOC. The highest DOC concentrations are associated with stemflow, overland
\end{abstract}

Responsible Editor: Mark Brush.

K. J. Cooper $(\bowtie) \cdot$ F. F. Whitaker · M. Naish .

E. L. Evans

School of Earth Sciences, University of Bristol,

Bristol BS8 1RJ, UK

e-mail: k.j.cooper@bristol.ac.uk

\section{A. M. Anesio}

School of Geographical Sciences, University of Bristol, Bristol BS8 1SS, UK

D. M. Reynolds

Centre for Research in Biosciences, University of the

West of England, Bristol BS16 1QY, UK recharge and dissolution hole waters which interact with bark lignin and exhibit strong terrestrial-derived characteristics. The groundwater samples exhibit the lowest concentrations of DOC and are comprised of refractory humic-like organic matter. The heterotrophic response seems to be controlled by the concentration of DOC in the sample. The terrestrially sourced humic-like matter in the stemflow and dissolution hole samples was highly labile, thus increasing the amount of biologically produced $\mathrm{CO}_{2}$ to drive dissolution. Based on the calculated respiration rates, microbial activity could enhance carbonate dissolution, increasing porosity generation by a maximum of $1 \% \mathrm{kyr}^{-1}$ at the top of the freshwater lens.

Keywords Dissolved organic carbon · Carbonate · Heterotrophic respiration - Recharge waters . Fluorescence EEM · Karstification

\section{Introduction}

Dissolved organic carbon (DOC) has a range of important functions in groundwater. One key role is as the prime source of carbon and energy to sustain heterotrophic microbial communities (Baker et al. 2000; Simon et al. 2010). During heterotrophic metabolism, organic carbon is consumed and $\mathrm{CO}_{2}$ is released into the groundwater (Wilhartitz et al. 2009). In carbonate environments, this additional $\mathrm{CO}_{2}$ has 
been suggested to play an important role in driving dissolution, enhancing secondary porosity in the shallow subsurface (Whitaker and Smart 2007a; Wilhartitz et al. 2009). However, few studies have considered the rate of $\mathrm{CO}_{2}$ generation (Wilhartitz et al. 2009) and the key factors influencing the response of the microbial community.

Previous microbial studies of karst aquifer systems have focused mostly on communities in caves in the vadose and phreatic zones, as well as spring waters (e.g. Birdwell and Engels 2010; Simon et al. 2010), with little attention to the broader aquifer system (e.g. Pronk et al. 2009). In the absence of photosynthesis, the groundwater organic carbon pool is sustained by recharge waters importing fresh DOC from the surface (Baker et al. 2000; Shabarova and Pernthaler 2010), as well as organic carbon being derived from the dissolution of carbonate minerals (Jin et al. 2014). Rainfall is the precursor to the majority of these recharging waters with interactions with vegetation, both the canopy (throughfall) and tree boles (stemflow), as well as the exposure carbonate surface, through surface runoff and infiltration. These interactions may alter the DOC concentrations along with the water composition, before reaching the groundwater.

Once the surface-derived carbon enters the aquatic system, various transformations, such as degradation and mineral sorption, can alter its original characteristics including bioavailability (Hur et al. 2009; Simon et al. 2010; Jin et al. 2014).

The composition of DOC in aquatic environments is inherently heterogeneous, comprising a complex mixture of organic molecules (Stedmon et al. 2003). The chemical nature of the coloured (chromophoric) fraction of the organic matter (CDOM) can be defined by its optical properties (Stedmon et al. 2003). Specific functional groups of this CDOM (flourophores) absorb and fluoresce at different emission/excitation wavelengths and these can be used to infer the composition of the organic matter (Stedmon et al. 2003; Birdwell and Engel 2010). CDOM can be characterised in threedimensions (as a function of excitation and emission wavelengths and intensity) using fluorescence excitation-emission matrices (EEMs) (Birdwell and Engel 2010).

The aim of this study is to understand the nature and significance of different delivery pathways of DOC and their significance for microbial respiration at the water table in a shallow pristine carbonate aquifer. The concentration and composition of organic carbon entering the aquifer are characterised by integrating DOC concentration data with UV-Vis absorption and fluorescence data. A range of recharge pathways have been sampled to understand the variability and transformation of the organic matter as it moves from the atmosphere to the water table. Incubation experiments have been employed to gather direct measurements of heterotrophic microbial activity in these differing water types and also to ascertain the potential $\mathrm{CO}_{2}$ influxes into this system via respiration. Finally, the impact of remineralization of organic carbon for carbonate dissolution was evaluated. This has implications ranging from porosity and permeability development in aquifers and hydrocarbon reservoirs to global carbon cycling.

\section{Materials and methods}

\section{Study site}

North Andros, the largest island in the Bahamian Archipelago $\left(3250 \mathrm{~km}^{2}\right)$, is situated on the windward side of the north-west Great Bahama Bank (Fig. 1). The majority of the island comprises Pleistocene deposits, mostly from the Grotto Beach formation, with very limited Holocene deposits (Rice Bay formation) along the east coast and more extensive tidal flats to the west of the island (Carew and Mylroie 1995; Whitaker and Smart 1997a). The Grotto Beach formation, thought to have been deposited during Marine Isotope Stage 5e (132-119 kyr bp), is mostly comprised of low-magnesium calcite with minor amounts of aragonite, which control the carbonate equilibria (Whitaker 1992; Whitaker and Smart 2007a). It also has a high hydraulic conductivity due to extensive secondary porosity and permeability at a range of scales developed by meteoric dissolution (Whitaker and Smart 1997b, 2000). These dissolutional features are manifest at the exposure surface as shallow epikarst ranging in scale from centimetre to decimetre kamanitzas and solution pipes to metre-scale dissolution pits, locally referred to as "banana holes" (Smart and Whitaker 1989), to pit caves and dissolutional collapse features including blue holes up to $300 \mathrm{~m}$ diameter and $>100 \mathrm{~m}$ deep (Whitaker 1998).

The island has a subtropical marine climate, with a warm wet season (May to November) dominated by 


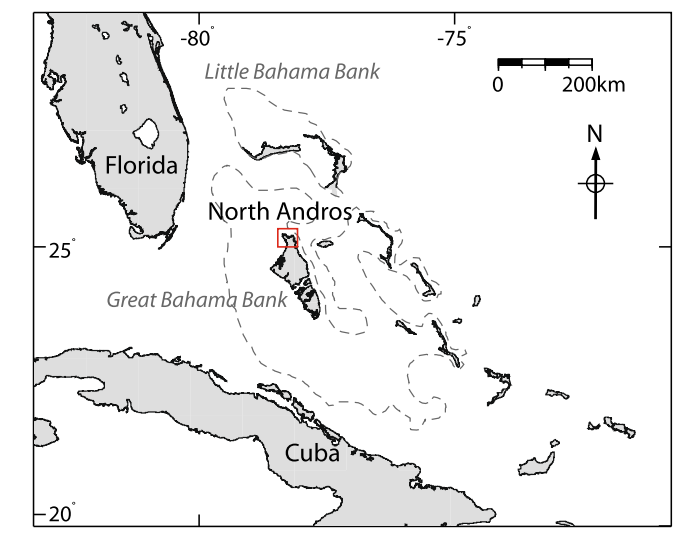

$\boxplus$ Dissolution holes

Trench

$\otimes$ Observation borehole

Rainfall, Throughfall, Stemflow \& Observation borehole

$\triangle$ Throughfall, Stemflow \& Overland flow

Throughfall, Stemflow, Trench \& Observation borehole

Trench \& Observation borehole is All sample types

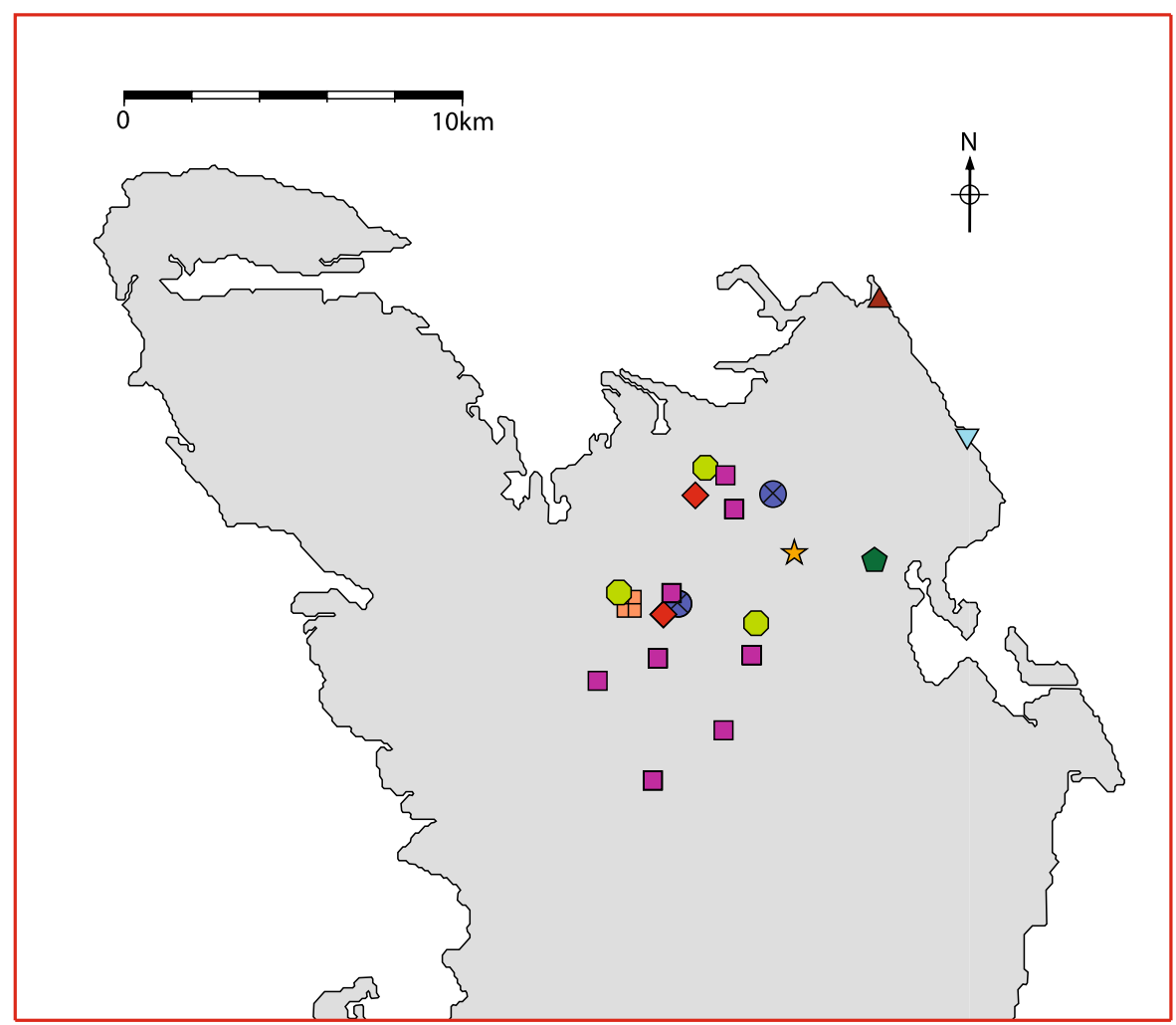

Fig. 1 North Andros Island, Bahamas with the sample locations marked

convective rainfall, and a cooler dry season (December to April) punctuated by rainfall from the occasional cold front (Whitaker and Smart 1997a). The mean average rainfall has been estimated at $1.3 \mathrm{myr}^{-1}$, with a potential evapotranspiration rate of $1.6 \mathrm{myr}^{-1}$ and an effective recharge $25 \%$ of mean annual rainfall (Whitaker and Smart 2007b). As the vadose zone is very thin (average $0.8 \mathrm{~m}$ ) (Whitaker and Smart 2007a), the karstic dissolution features act as conduits focussing recharge rapidly to the water table. The majority of the recharge occurs during heavy storm events, during which the water table responds within $3 \mathrm{~h}$ on North Andros (Cooper 2015), and on nearby Grand Bahama 45-75\% of the rainfall reaches the water table within $12 \mathrm{~h}$ of the rain (Whitaker and Smart 2007b).

Vegetation on North Andros is predominantly pine forest (Pinus caribaea var. bahamensis), with an 
understory of palms and poisonwood (Henry 1974; Sanchez et al. 2014). Due to the thin vadose zone, the pine forest is poorly developed and provides a sparse canopy cover (Henry 1974). There are restricted areas of hardwood and coppice vegetation, often located where the vadose zone is locally thicker. Recharging water infiltrates very rapidly into the vadose zone through the well-developed epikarst, with overland flow to surface dissolution features over short distances $(<$ metres). Much of the surface is broken limestone with a thin cover of pine litter and isolated patches of immature soil (Little et al. 1973). Within the pine forest, the dominant soil is a mineral-poor black soil which comprises largely organic matter at various stages of decomposition (Little et al. 1973). An immature lateritic soil is present in some of the surface dissolution features, as described in Eleuthera by Foos (1989).

Meteoric recharge maintains a lens-shaped body of groundwater which is separated from underlying denser saline waters by a fresh-salt water mixing zone (Whitaker and Smart 1997a). The distribution of freshwater lens thickness is controlled by the size and shape of the island, effective recharge and aquifer porosity and permeability (Cant and Weech 1986). The freshwater lens on North Andros is dissected by a number of tidal creeks which limit the thickness of the freshwater lens (Whitaker and Smart 1997a). In the study area (Fig. 1) the lens is approximately $10-12 \mathrm{~km}$ wide and prior to groundwater extraction attained a maximum thickness of $34 \mathrm{~m}$ (Little et al. 1973). This lens provides potable water for the local population, and from 1972 to 2011 water was barged to the neighbouring populous island of New Providence (Cant and Weech 1986; Lloyd et al. 1992). The freshwater was extracted via an extensive network of cruciform trenches, pumped at low rates from a central point to minimise saline up-coning (Lloyd et al. 1992). Over a swath extending $c .5 \mathrm{~m}$ either side of each trench, vegetation was cleared the top $20-30 \mathrm{~cm}$ of the vadose zone scraped off and the surface graded to promote overland flow to the trenches. Observation boreholes are also located in the study area, facilitating sampling of waters from the top of the freshwater lens.

Sampling sites and methods

The sampling locations were predominantly within the pine forest in the northern part of the island (Fig. 1), and the samples were collected over the course of two wet season sampling campaigns: September to October in 2011 and June to July in 2012, representing the late and early wet season respectively.

Samples were collected to represent different discrete recharge pathways (Fig. 2) and include: rain $(\mathrm{n}=11)$; throughfall, rain percolating through the vegetation canopy $(n=46)$; stemflow, flow down the tree trunks $(\mathrm{n}=35)$; overland flow $(\mathrm{n}=13)$ and samples from the top of the freshwater lens from trenches $(\mathrm{n}=25)$, dissolution holes $(\mathrm{n}=9)$ and boreholes $(\mathrm{n}=23)$.

Rain and throughfall were collected using plastic sheets $\left(2 \mathrm{~m}^{2}\right)$, previously washed with deionized water and then rinsed with sample, held at 1-1.5 m above ground level to minimise splash-back. Stemflow was intercepted using a split pipe encircling the trunk and channelling flow into a bottle which was collected after rainfall events. Overland flow was sampled from bare rock surfaces, solution pipes discharging into the caves, and scraped areas adjacent to trenches. Natural dissolution holes and trench waters were grab sampled, and boreholes were pumped from just below the water table using a peristaltic pump on a low flow setting through a flow-through cell (U.S. Environmental Protection Agency 2010).

Samples were filtered using pre-combusted Whatman GF/F $(0.7 \mu \mathrm{m})$ glass fibre filters and stored in glass vials which had been acid washed in $10 \% \mathrm{HCl}$, rinsed, furnaced for $4 \mathrm{~h}$ at $550{ }^{\circ} \mathrm{C}$ and sealed with combusted aluminium foil. They were frozen immediately after collection, and kept frozen during transport back to the UK and until analysis of the TOC, $\mathrm{UV}-\mathrm{V}$ is and fluorescence analysis was undertaken.

\section{Chemical analysis}

\section{DOC}

DOC analysis was undertaken using a Shimadzu TOC5000A total organic carbon analyser as non-purgeable organic carbon using high temperature combustion and a high-sensitivity catalyst. The variance on the repeat samples was less than $1 \%$.

\section{Absorption}

Ultraviolet-visible (UV-Vis) absorbance spectra from 200 to $800 \mathrm{~nm}$ was obtained at $1 \mathrm{~nm}$ increments, using 


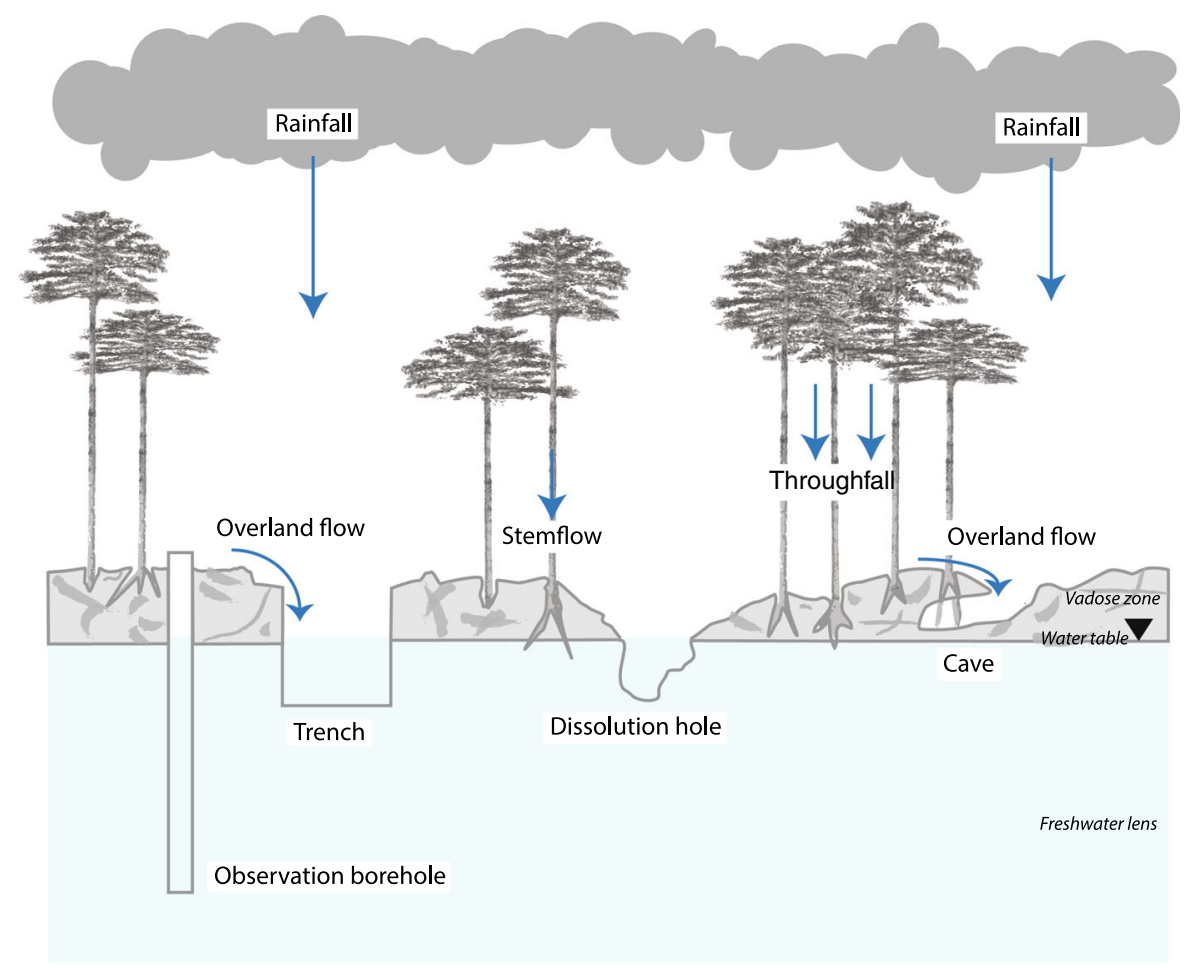

Fig. 2 Schematic showing the recharge pathways on North Andros. The effects of interaction of rainfall with the vegetation via the canopy and the trunk are evaluated using samples of throughfall and stemflow respectively. At the ground recharge infiltrates to the freshwater lens directly, via dissolution holes,

a Cary $60 \mathrm{UV}-\mathrm{Vis}$ with a $10 \mathrm{~mm}$ path-length quartz cell for a subset of 69 samples. The absorbance spectra are converted to absorption coefficients using Eq. 1 (Helms et al. 2008):

$a=2.303 \mathrm{~A} / l$

where $a=$ absorption coefficient $\left(\mathrm{m}^{-1}\right), A=\mathrm{ab}-$ sorbance (dimensionless) and $l=$ path-length (m). The absorption spectrum for CDOM, the fraction of dissolved organic matter which absorbs ultraviolet and visible light, increases exponentially (approximately) with decreasing wavelength (Twardowski et al. 2004; Helms et al. 2008). Thus spectra can provide a number of metrics relating to organic carbon composition which are largely independent of the concentration (Helms et al. 2008).

The ratio of absorption coefficient at $250-365 \mathrm{~nm}$ $\left(E_{2}: E_{3}\right)$ was used in this investigation to reflect the relative size of the CDOM molecules; larger molecules lead to a decrease in $\mathrm{E}_{2}: \mathrm{E}_{3}$ as stronger light solution pipes and caves. Overland flow is limited, except where the epikarst has been removed adjacent to the trenches. The caves provide access to water sourced by overland flow as it percolates through the vadose zone

absorption by high molecular weight CDOM occurs at longer wavelengths (Helms et al. 2008). CDOM aromaticity correlates positively with the absorption coefficient at a wavelength of $254 \mathrm{~nm}$ (SUVA254), when normalised by the DOC concentration (mg C L ${ }^{-1}$ ) (Weishaar et al. 2003). The normalised absorption coefficient at a wavelength of $280 \mathrm{~nm}$ $\left(\varepsilon_{280}\right)$ is positively correlated with both the molecular weight and aromaticity of the humic substances (Chin et al. 1994; Helms et al. 2008). Previous studies have reported a positive relationship between the SUVA254 and $\varepsilon_{280}$ as both are measures of the aromaticity, and an inverse relationship between $\varepsilon_{280}$ and $E_{2}: E_{3}$ reflecting control by molecular weight (Santos et al. 2009).

Further information was obtained from the spectrum using a single exponential decay function fitted to the data in order to obtain the spectral slope (Stedmon and Markager 2001; Helms et al. 2008). In line with Helms et al. (2008), this decay function should have an 
$\mathrm{R}^{2}<0.9$ in order for the decay function to be significant. The spectral slope can indicate characteristics of the CDOM but, because of complexities in the form of the decay function, it can be very dependent on the range of wavelengths over which it is calculated (Helms et al. 2008). Helms et al. (2008) suggested that the ratio between spectra slope values, $S_{R}$, over two short ranges of wavelengths, 275-295 and $350-400 \mathrm{~nm}$, is more sensitive to shifts in molecular weight and/or source of CDOM. As for $E_{2}: E_{3}$, the stronger absorbance of the high molecular weight molecules at longer wavelength would decrease the $S_{R}$, resulting in an inverse relationship between $S_{R}$ and molecular weight (Helms et al. 2008).

\section{Fluorescence analysis}

Fluorescence analysis $(n=157)$ was carried out using a Fluorolog-3 spectrofluorometer with a xenon lamp excitation source and a quartz cuvette with a $10 \mathrm{~mm}$ path-length. Instrument stability and performance were checked daily by measuring the Raman peak of Milli-Q water using an excitation wavelength $\left(\lambda_{\mathrm{ex}}\right)$ of $350 \mathrm{~nm}$, and an emission wavelength $\left(\lambda_{\mathrm{em}}\right)$ of $397 \mathrm{~nm}$. EEM analysis was undertaken over using a $\lambda_{\text {ex }}$ range of $230-420 \mathrm{~nm}$ and a $\lambda_{\text {em }}$ range $290-550 \mathrm{~nm}$, at increments of $5 \mathrm{~nm}$ for the bulk samples and $2 \mathrm{~nm}$ for the inoculation samples, with an integration time of $0.1 \mathrm{~s}$ and a bandpass of $5 \mathrm{~nm}$ for both excitation and emission. Blank Milli-Q samples were run daily.

The EEMs were recorded in signal divided by reference mode, and incorporated instrument-specific corrections to adjust for spectral biases (Lawaetz and Stedmon 2009). Inner-filter effects were corrected for using the UV-Vis absorbance spectra (Ohno 2002). When sample volumes were too low to perform this measurement, data from a sample of the same type of water with a similar DOC concentration was used for the correction. Although this is not best practice, it was suggested to be preferable to UV-Vis correction and as the samples had been filtered previous work has suggested there is a linear correlation between CDOM adsorption and DOC concentration (Zhang et al. 2005). The intensity of the fluorescence was converted from an arbitrary unit (counts per second-CPS), to a quantifiable inter-comparable Raman unit (RU), by normalising EEM data to the water Raman signal of blank Milli-Q samples, specifically the area under the Raman peak $\left(\lambda_{\mathrm{ex}}=350 \mathrm{~nm}\right)$ between 370 and
$430 \mathrm{~nm}$, as per the method detailed in Lawaetz and Stedmon (2009). The blank EEM was then subtracted from the EEM of the sample using a custom written script in MATLAB (Mathworks, MA) software, thus removing the water signature of the sample and correcting for daily instrumental variations. As a number of the sample groups contain $<20$ samples it was not possible to perform the commonly used PARAFAC, a principle component analysis methodology, for the samples groups as it would not be statistically robust (Stedmon and Bro 2008), instead different components were identified using an "algorithm-based" approach, which defines regions of interest (highlighted in Fig. 3) and systematically extracts the maximum intensity within that region (Korak et al. 2014).

EEMs of natural waters have a number of well characterised component fluorophores which are associated with humic-like and protein-like substances (Coble et al. 2014; Korak et al. 2014; Birdwell and Engel 2010; Stedmon et al. 2003; Baker and LamontBlack 2001). The humic-like substances emit light between 350 and $500 \mathrm{~nm}$ and can give rise to distinct peaks indicative of humic acid (C peak), fulvic acid $\left(A_{C}\right.$ peak) and autochthonous humic-like material $\left(A_{M}\right.$ and M peaks) (Coble et al. 2014; Birdwell and Engel

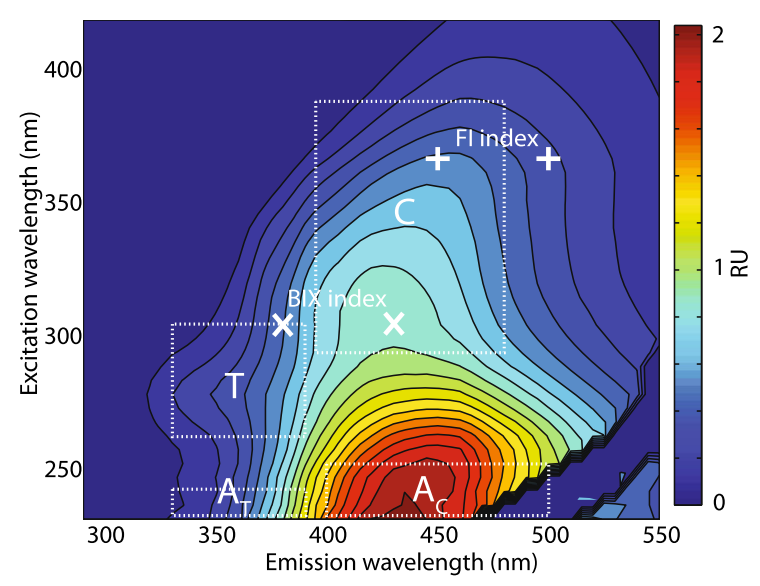

Fig. 3 Typical EEM showing the humic-like $\mathrm{C}$ peak region $\left(\lambda_{\mathrm{ex}} 300-390 \mathrm{~nm}, \lambda_{\mathrm{em}} 395-480 \mathrm{~nm}\right)$ and $\mathrm{A}_{\mathrm{C}}$ peak region $\left(\lambda_{\mathrm{ex}}\right.$ $\left.220-260 \mathrm{~nm} \lambda_{\text {em }} 400-500 \mathrm{~nm}\right)$, and the protein-like $\mathrm{T}$ peak region $\left(\lambda_{\text {ex }} 270-310 \mathrm{~nm}, \lambda_{\mathrm{em}} 330-390 \mathrm{~nm}\right)$ and $\mathrm{A}_{\mathrm{T}}$ peak region ( $\lambda_{\text {ex }} 210-250 \mathrm{~nm}, \lambda_{\text {em }} 330-380 \mathrm{~nm}$ ). The fluorescence index (FI) is the ratio between $\left(\lambda_{\text {ex }} 370 \mathrm{~nm}, \lambda_{\text {em }} 450 \mathrm{~nm}\right)$ and $\left(\lambda_{\text {ex }}\right.$ $\left.370 \mathrm{~nm}, \lambda_{\mathrm{em}} 500 \mathrm{~nm}\right)$, marked with + . The BIX index is the ratio between $\left(\lambda_{\mathrm{ex}} 310 \mathrm{~nm}, \lambda_{\mathrm{em}} 380 \mathrm{~nm}\right)$ and $\left(\lambda_{\mathrm{ex}} 310 \mathrm{~nm}, \lambda_{\mathrm{em}}\right.$ $430 \mathrm{~nm}$ ), marked with $x$ 
2010). The protein-like substances emit light at lower values between 300 and $350 \mathrm{~nm}$, and can be subdivided into tryptophan-like $\left(\mathrm{A}_{\mathrm{T}}\right.$ and $\left.\mathrm{T}\right)$ and tyrosine peaks $\left(A_{B}\right)$ (Coble et al. 2014; Birdwell and Engel 2010). The peak intensities for the most commonly peaks- $\mathrm{A}_{\mathrm{C}}, \mathrm{C}, \mathrm{T}$ and $\mathrm{A}_{\mathrm{T}}$-were identified (see Fig. 3 for the different peak regions).

Ratios between these florophores were used to provide insights into the composition and source of the organic matter. The ratio $\mathrm{A}_{\mathrm{C}}: \mathrm{C}$ was used to indicate the maturity of the humic-like material, with the $\mathrm{C}$ peak representing older, more degraded and humified material (Huguet et al. 2009). The ratio T:C was used to reflect the productivity of the aquatic environment, with increases in $\mathrm{T}$ peak intensities (tryptophan) indicating microbial activity (Huguet et al. 2009). Specific fluorescence indices were also used to assess the origin of the organic matter (Huguet et al. 2009; Birdwell and Engels 2010). The fluorescence index (FI) is the ratio of ( $\left.\lambda_{\mathrm{em}} 450 \mathrm{~nm}, \lambda_{\mathrm{ex}} 370 \mathrm{~nm}\right)$ to $\left(\lambda_{\mathrm{em}}\right.$ $500 \mathrm{~nm}, \lambda_{\mathrm{ex}} 370 \mathrm{~nm}$ ), and provides a measure of the relative proportions of terrestrial-derived to microbialderived humic-like material (McKnight et al. 2001). Terrestrial-derived humic-like acids, from plant litter and soils, have a higher aromatic carbon content than their microbial counterparts. The FI uses this difference to indicate the potential source of the material (McKnight et al. 2001), with FI values $\leq 1.4$ indicating a terrestrial origin, and values $\geq 1.9$ indicating a microbial source.

The biological/autochthonous index (BIX) is the ratio between $\left(\lambda_{\mathrm{em}} 380 \mathrm{~nm}, \lambda_{\mathrm{ex}} 310 \mathrm{~nm}\right)$ and $\left(\lambda_{\mathrm{em}}\right.$ $430 \mathrm{~nm}, \lambda_{\mathrm{ex}} 310 \mathrm{~nm}$ ) and assesses the contribution of the in situ biologically-produced organic matter, $M$ peak (Huguet et al. 2009). Values of BIX between 0.8 and 1 are attributed to the broadening of the emission spectra by increased $M$ peak contributions, suggesting a microbial source from the DOM. In contrast, low values, $\leq 0.6$, indicate little contribution from microbial production and can be attributed to a terrestrial source, such as plants and soil (Birdwell and Engels 2010; Huguet et al. 2009).

Microbial response to the different types of water

Samples of rain, throughfall, stemflow, overland flow and dissolution hole waters collected during a single heavy rainfall event in September 2011 were used to assess the bioavailability of organic carbon to the groundwater aerobic microbial community $(\mathrm{n}=9)$. The groundwater microbial community used for the experiments was collected from the water table in a borehole with a vadose zone thickness of $1.1 \mathrm{~m}$. The samples were filtered, using pre-combusted GF/F $(0.7 \mu \mathrm{m})$ glass fibre filters, prior to mixing with the unfiltered groundwater sample, with a ratio of 70:30 recharge water to groundwater, and decanted in triplicate into $60 \mathrm{ml}$ biological oxygen demand (BOD) bottles. Unfiltered groundwater was used in triplicate as a control. Initial dissolved oxygen (DO) measurements were taken using a Hach HQ40d DO meter and then the bottles were incubated in the dark at approximately $30{ }^{\circ} \mathrm{C}$, which is similar to the temperature of the groundwater at the top of the lens during these months $\left(27-31^{\circ} \mathrm{C}\right)$ (Cooper 2015). After $\sim 50 \mathrm{~h}$, a second DO measurement was taken, using the same meter. The average respiration rate of the aerobic heterotrophic microbial communities was calculated in $\mu \mathrm{g} \mathrm{C} \mathrm{L}^{-1} \mathrm{~h}^{-1}$ by converting the moles of $\mathrm{O}_{2}$ consumed to moles of $\mathrm{C}$ respired, assuming a one to one molar conversion. This was then used to calculate the concentration of DOC consumed over the course of the incubation, assuming that one mole of DOC is equal to one mole of carbon respired and that the rate was constant. This was then expressed as a percentage of the initial DOC concentration and used to estimate the bioavailability for each sample.

The average respiration rates were then used to estimate the possible rate of dissolution of the host carbonate rock through the release of $\mathrm{CO}_{2}$ into the groundwater. First, the respiration rates were corrected for the ratio of inoculant water to groundwater to produce a rate based on just the inoculant waters. The average bioavailability for each water type was calculated in a similar fashion to the individual water, described above. Obviously the remainder of the DOC is likely to be somewhat bioavailable, but as the rates of consumption are known to decrease over time this was thought to be a valid assumption without further rate decay experiments. The total volume of recharge waters was calculated for the sampling area $\left(20 \mathrm{~km}^{2}\right)$. The minimum estimated rate was based on recharge of $0.34 \mathrm{myr}^{-1}$, on the assumption that the dissolution occurs after evapotranspiration, and the maximum rate based on recharge of $0.94 \mathrm{myr}^{-1}$, which assumed dissolution was complete prior to evapotranspiration (Whitaker 1992; Whitaker and Smart 2007b). The volumes of recharge routed via different pathways are 
poorly constrained, but it was estimated that for this forested areas on North Andros, direct infiltration of rainfall and throughfall account for 15 and $30 \%$ of recharge respectively, some $5 \%$ of recharge is routed directly to the subsurface via stemflow (Levia and Frost 2003), $30 \%$ enters by percolation of overland flow and $20 \%$ via dissolution holes (Whitaker and Smart 2007b). For each pathway, the average concentration of DOC was used to calculate the annual incoming DOC budget. The bioavailable fraction of the DOC budget was then calculated and used to infer the dissolution rate, using the assumption that one mole of $\mathrm{C}$ respired was equal to one mole of $\mathrm{CaCO}_{3}$ dissolved and that the dissolution was focussed within $10 \mathrm{~cm}$ of the water table.

\section{Statistical analysis}

Where the variance between water types was shown to be equal using a Levene's test, the statistical significance of this difference was tested using a one-way/ two-way ANOVA followed by post hoc Tukey test. When the variance was shown not to be equal, a Kruskal-Wallis test followed by pair-wise comparisons was used to assess the statistical significance. Testing the variation between two sample sets was undertaken using either a paired-T test or a Wilcoxon's signed ranks test on the arithmetic mean, depending on homogeneity of the sample variance. The correlation between two variables was calculated using least-square regression. Statistical tests were carried out using SPSS software, and significance is reported as probability in brackets with the highest confidence level.

\section{Results}

DOC

DOC concentrations ranged from $0.33 \mathrm{mg} \mathrm{C} \mathrm{L}^{-1}$ to a maximum of $60.3 \mathrm{mg} \mathrm{C} \mathrm{L}^{-1}$, and are summarised in Fig. 4. The concentration of DOC in the majority of rainfall samples was low $\left(<3 \mathrm{mg} \mathrm{C} \mathrm{L}^{-1}\right)$, and passage through the canopy leads to slight enrichment in DOC, although sample populations were not statistically significantly different (Krustal-Wallis, post hoc pairwise comparisons, $p>0.01)$. The stemflow samples had the highest measured DOC concentrations, with a

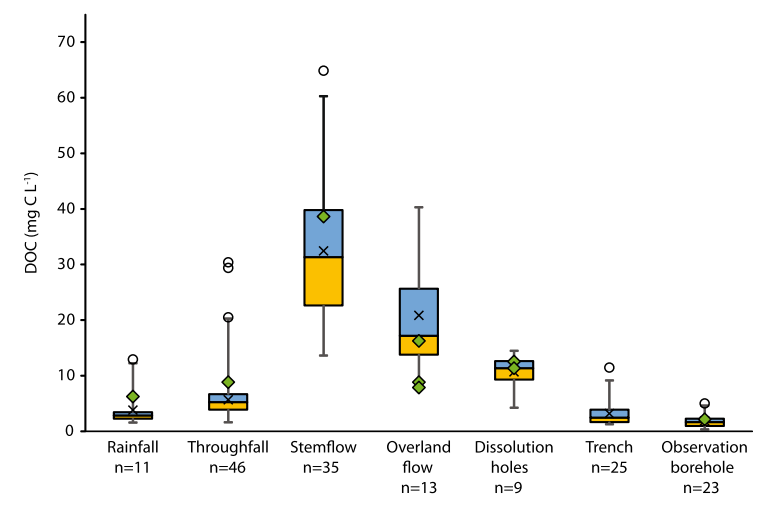

Fig. 4 Box and whisker diagram of the DOC concentrations of the different water types. The $x$ denotes the arithmetic mean, the whiskers are the maximum and minimum values and the green diamonds are the values for the samples used in the inoculation experiment. The circles are the outliers in the data set $(> \pm 2 \mathrm{SD}$ from the mean)

mean of $32.4 \mathrm{mg} \mathrm{C} \mathrm{L}^{-1}$, though not significantly higher than that of overland flow waters (KrustalWallis, post hoc pair-wise comparisons, $p<0.01$ ). In comparison, all samples from the water table were significantly depleted in DOC, with very low concentrations in trench waters and those from boreholes, while waters from dissolution holes had rather higher values (Krustal-Wallis, post hoc pair-wise comparisons, $p<0.02$ ). There was no significant differences between the DOC of samples collected in the early compared to the late wet season (Wilcoxon signed rank test, $p<0.05$ ).

\section{Absorption}

Representative UV-Vis absorption spectra for the different water types are shown in Fig. 5. To avoid possible concentration interferences, the absorption coefficients were normalised by the DOC concentrations and reported as specific absorptivity $\left(\mathrm{g}^{-1}\right.$ $\mathrm{C} \mathrm{L} \mathrm{cm}^{-1}$ ) (Santos et al. 2009). The stemflow samples had higher specific absorptivity throughout the spectra, when compared to the other water types (Fig. 5), with the trench and borehole waters generally exhibiting the lowest values. The latter also exhibited nonexponential spectra curves which were relatively low and flat at longer wavelengths, with an exponential increase at $>c .225 \mathrm{~nm}$. This was not the case for the other water types which, in general, showed an exponential increase in absorptivity over the entire 


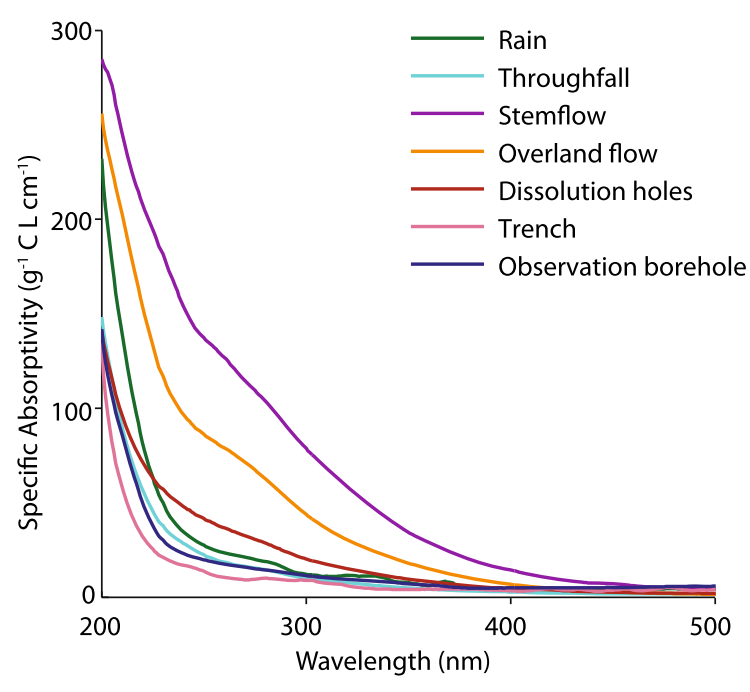

Fig. 5 Representative specific absorptivity $\left(\mathrm{g}^{-1} \mathrm{C} \mathrm{L} \mathrm{cm}{ }^{-1}\right)$ UV-Vis spectra, where the specific absorbance has been normalised by the DOC concentration, for each of the seven water types. The stemflow, overland flow and dissolution hole examples show an exponential shaped spectra. The rain, throughfall, borehole and trench water examples have a flatter section at higher wavelengths and only start to increase exponentially at $\sim 225 \mathrm{~nm}$. These samples tend to have lower specific absorptivity than the stemflow, overland flow and dissolution hole samples

spectral range. This flattening affected the spectral slope parameter, $S_{R}$, as a single exponential decay function could not be fitted well $\left(\mathrm{R}^{2}>0.9\right)$ to samples with low absorbance at high wavelengths and therefore $S_{R}$ was only calculated for 42 samples, which excluded the majority of the trench and observation borehole waters, whereas the other metrics were calculated for all samples (see Table 1).

As with the DOC data, there was a high variability within the individual water types for each metric, though UV-Vis spectra were only measured for a subset of samples $(n=69)$. The arithmetic mean values for the two indicators of molecular weight $\left(\mathrm{E}_{2}: \mathrm{E}_{3}\right.$ and $\left.\varepsilon_{280}\right)$ showed a clear positive correlation (Fig. 6; least-square regression $r^{2}=0.74$ ), excluding the samples from boreholes and trenches which showed a reduction in $\varepsilon_{280}$ due to reduction of absorbance at wavelengths $<280 \mathrm{~nm}$. In contrast, strong correlations existed for all the water types between the measures of aromaticity, SUVA254, $\varepsilon_{280}$ and $S_{R}$, (least-square regression $r^{2}=0.99$ for SUVA254 and $\varepsilon_{280}$ and least-square regression $r^{2}=0.99$ and $r^{2}=0.59$ for $S_{R}$ with SUVA254 and $\varepsilon_{280}$ respectively). These spectral parameters showed that the aromaticity was lowest in the rainfall and throughfall with a significant increase in the stemflow and overland flow (one-way ANOVA, post hoc Tukey, $p<0.01)$.

\section{Fluorescence}

\section{EEM classification and water types}

The peaks identified in the EEMs and their fluorescence intensities were variable within and between different sample types (example shown in Fig. 7). The most common peaks were $\mathrm{C}$ and $\mathrm{A}_{\mathrm{C}}$, humic-like materials, appearing in all but 18 samples. In most samples, the protein-like peaks were less common, $\mathrm{T}$ being more prevalent than $\mathrm{A}_{\mathrm{T}}$. As the $\mathrm{A}_{\mathrm{T}}$ peak is small, it may not have been identifiable in the lower resolution EEMs and therefore could be under-represented in the data. Where present, the humic-like peaks generally exhibited the highest fluorescence intensities, with the $\mathrm{A}_{\mathrm{C}}$ peak being dominant compared to peak $\mathrm{C}$, in $62 \%$ of samples. The fluorescence

Table 1 The mean \pm 1 SD values for SUVA254, $\varepsilon 280, E_{2}: E_{3}$ and $S_{R}$ metrics of each water type

\begin{tabular}{llllllll}
\hline & Rain $\mathrm{n}=3$ & $\begin{array}{l}\text { Throughfall } \\
\mathrm{n}=17\end{array}$ & $\begin{array}{l}\text { Stemflow } \\
\mathrm{n}=18\end{array}$ & $\begin{array}{l}\text { Overland flow } \\
\mathrm{n}=3\end{array}$ & $\begin{array}{l}\text { Dissolution hole } \\
\mathrm{n}=5\end{array}$ & $\begin{array}{l}\text { Trench } \\
\mathrm{n}=12\end{array}$ & $\begin{array}{l}\text { Borehole } \\
\mathrm{n}=11\end{array}$ \\
\hline $\begin{array}{l}\text { SUVA254 } \\
\left(\mathrm{L} \mathrm{mg} \mathrm{m} \mathrm{m}^{-1}\right)\end{array}$ & $2.6 \pm 1.5$ & $4.0 \pm 2.1$ & $8.8 \pm 2.1$ & $7.2 \pm 3.4$ & $5.0 \pm 0.6$ & $4.4 \pm 2.3$ & $5.3 \pm 2.6$ \\
$\varepsilon 280\left(\mathrm{~L} \mathrm{~g}^{-1} \mathrm{~cm}^{-1}\right)$ & $19.0 \pm 12.7$ & $29.7 \pm 16.8$ & $68.6 \pm 17.1$ & $55.9 \pm 26.6$ & $35.8 \pm 4.6$ & $36.2 \pm 19.3$ & $43.3 \pm 24.1$ \\
$\mathrm{E}_{2}: \mathrm{E}_{3}$ & $3.9 \pm 1.0$ & $4.7 \pm 1.5$ & $5.1 \pm 0.5$ & $5.4 \pm 0.8$ & $4.7 \pm 1.4$ & $2.9 \pm 1.3$ & $2.2 \pm 0.9$ \\
$\mathrm{~S}_{\mathrm{R}}$ & $1.9 \pm 0.3$ & $1.2 \pm 0.3$ & $0.7 \pm 0.1$ & $1.3 \pm 0.7$ & $1.0 \pm 0.04$ & $1.5 \pm 0.5$ & 1.1 \\
& $(\mathrm{n}=2)$ & $(\mathrm{n}=12)$ & $(\mathrm{n}=18)$ & $(\mathrm{n}=3)$ & $(\mathrm{n}=3)$ & $(\mathrm{n}=3)$ & $(\mathrm{n}=1)$ \\
\hline
\end{tabular}

For some water types $S_{R}$ could only be calculated for a subset of samples (sample size in brackets) 

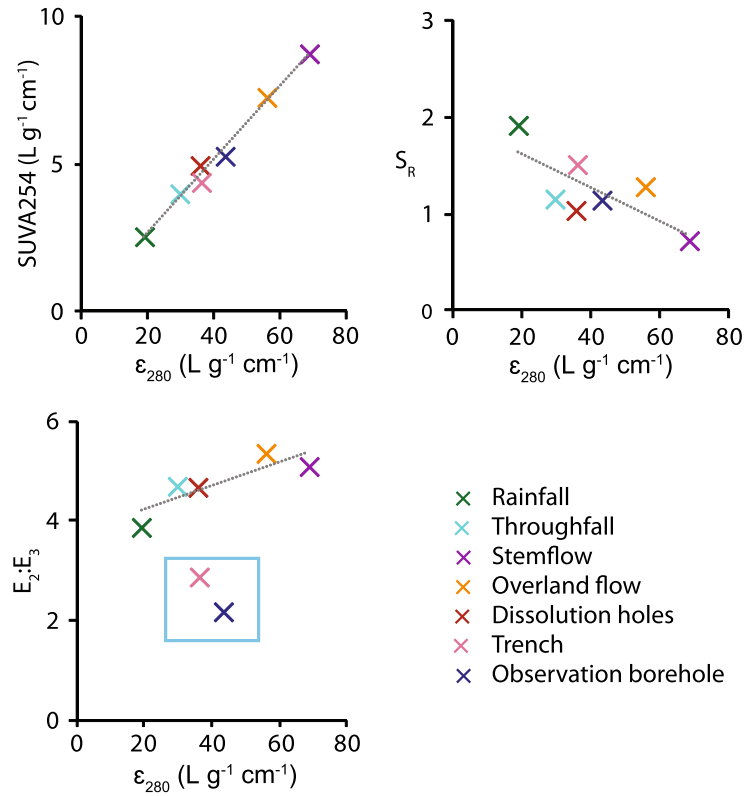

$$
\begin{array}{ll}
\times & \text { Rainfall } \\
\times & \text { Throughfall } \\
\times & \text { Stemflow } \\
\times & \text { Overland flow } \\
\times & \text { Dissolution holes } \\
\times & \text { Trench } \\
\times & \text { Observation borehole }
\end{array}
$$

Fig. 6 Relationships between the arithmetic mean values for each water type for the absorption metrics: SUVA254, $\varepsilon_{280}, S_{R}$ and $\mathrm{E}_{2}: \mathrm{E}_{3}$. There is a strong positive correlation (indicated by the dotted grey line) between SUVA254 and $\varepsilon_{280}$ and between $\mathrm{E}_{2}: \mathrm{E}_{3}$ and $\varepsilon_{280}$ (excluding trench and observation borehole samples, boxed), and an inverse correlation between $\varepsilon_{280}$ and $S_{R}$ (and also SUVA254 not shown here)

intensities range from 0.04 to $87.46 \mathrm{RU}$ with the highest intensities, $>15 \mathrm{RU}$ being associated with the $\mathrm{A}_{\mathrm{C}}$ peak.

There were systematic differences between the water types. The EEMs obtained from rain samples were largely dominated by peak $\mathrm{C}$; whereas the throughfall showed much more variability in the EEMs, with $\mathrm{C}, \mathrm{A}_{\mathrm{C}}$ and $\mathrm{A}_{\mathrm{T}}$ all being dominant in different samples. The $A_{C}$ peak was dominant for stemflow, overland flow and dissolution hole samples. These also exhibited the highest fluorescence intensities. The trench samples showed more variability, with an increase in the prevalence of the $\mathrm{C}, \mathrm{T}$ and $\mathrm{A}_{\mathrm{T}}$ peaks. The borehole samples were dominated by the $\mathrm{C}$ peak.

Given the range of EEM groups represented in the throughfall, it is not surprising that the $\mathrm{C} / \mathrm{A}_{\mathrm{C}}$ and $\mathrm{C} / \mathrm{T}$ ratios varied widely (Fig. 8). $\mathrm{C} / \mathrm{A}_{\mathrm{C}}$ was also variable for rainfall, but most $\mathrm{C} / \mathrm{T}$ ratios were $<1$. In contrast, the stemflow, overland flow and dissolution hole waters all show $\mathrm{A}_{\mathrm{C}}$ and $\mathrm{C}$ peaks dominant over $\mathrm{T}$ peak. The trench and borehole samples spanned a range of $\mathrm{C} / \mathrm{A}_{\mathrm{C}}$ and $\mathrm{C} / \mathrm{T}$ ratios. However, most trench samples had low $\mathrm{C} / \mathrm{A}_{\mathrm{C}}$ ratios, reflecting the dominance of the
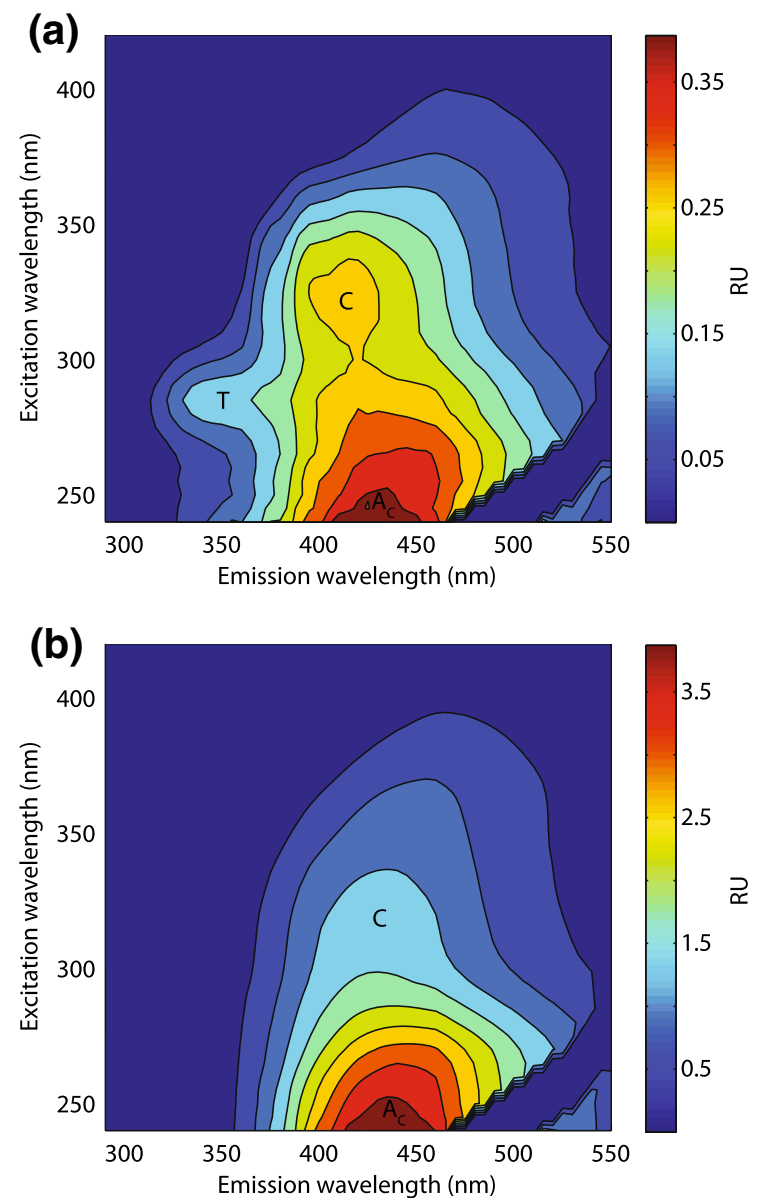

Fig. 7 Example EEMs for a sample with a defined $\mathrm{A}_{\mathrm{C}}, \mathrm{C}$ and $\mathrm{T}$ peak, where the $A_{C}$ peak is dominant and $\mathbf{b}$ sample with a large $A_{C}$ peak and a shouldering $C$ peak. Note order of magnitude change in RU between two EEMs

$\mathrm{A}_{\mathrm{C}}$ peak, with $\mathrm{C} / \mathrm{T}$ ratios similar to the stemflow/ overland flow/dissolution hole samples, although some samples had a ratio $<1$. The borehole samples fell into two distinct groupings of $\mathrm{C} / \mathrm{A}_{\mathrm{C}}$ ratio, either $<0.8$ or $>1.5$.

\section{Fluorescence indexes}

The FI and BIX were plotted for each water type in Fig. 9 to investigate the differences in the source of the DOC. The rain samples were defined as dominantly microbial-sourced based on both the indexes, although the variability in the FI and BIX is high. Some throughfall samples appeared to be terrestrial-derived (most clearly based on FI), and others microbialsourced. Only the stemflow and overland flow had 

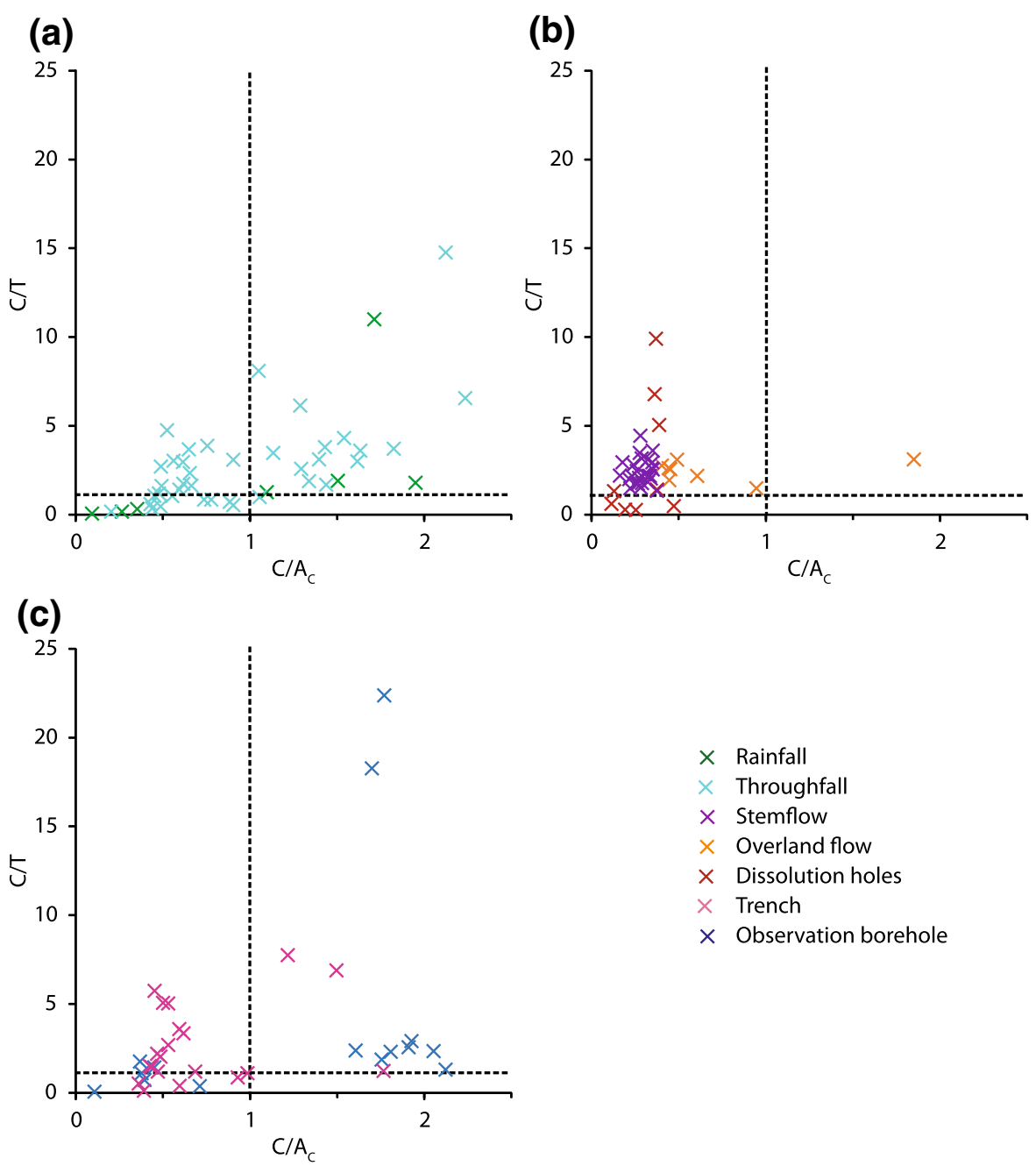

Fig. 8 Scatterplots of the $\mathrm{C} / \mathrm{T}$ and $\mathrm{C} / \mathrm{A}_{\mathrm{C}}$ ratios for the different water types for a rain and throughfall EEMs, $\mathbf{b}$ stemflow, overland flow and dissolution hole waters and $\mathbf{c}$ trench and borehole samples

clearly distinct BIX and FI values which indicated a terrestrial source (Kruskal-Wallis, post hoc pair-wise comparisons, $p<0.05$ ). The dissolution hole samples were similar to stemflow and overland flow, but show more spread in both the BIX and FI. The trench samples resembled the throughfall, with a spread of high BIX values, whilst samples from boreholes, spanned a large range of the FI values.

\section{Microbial response and DOC bioavailability}

Microbial respiration in the control groundwater sample from the borehole indicated a baseline of $3.41 \pm 0.53 \mu \mathrm{g} \mathrm{C} \mathrm{L}^{-1} \mathrm{~h}^{-1}$ (Fig. 10). In comparison, the addition of all water types, apart from rain, stimulated the microbial community within the groundwater sample. There was a positive correlation between DOC concentration of the inoculant water and the carbon respired in the inoculated groundwater sample, with the exception of the slow flow overland sample, which was excluded from subsequent interpretation (least-square regression $r=0.44$; Fig. 10).

The EEMs of the inoculant waters showed fluorescence intensity dominated by either the $\mathrm{A}_{C}$ or $\mathrm{T}$ peak. The maximum intensity of the EEM of the inoculant showed a positive correlation with the respiration measurements of the corresponding inoculated sample. Similarly, an increase in the $A_{C} / T$ ratio in the 

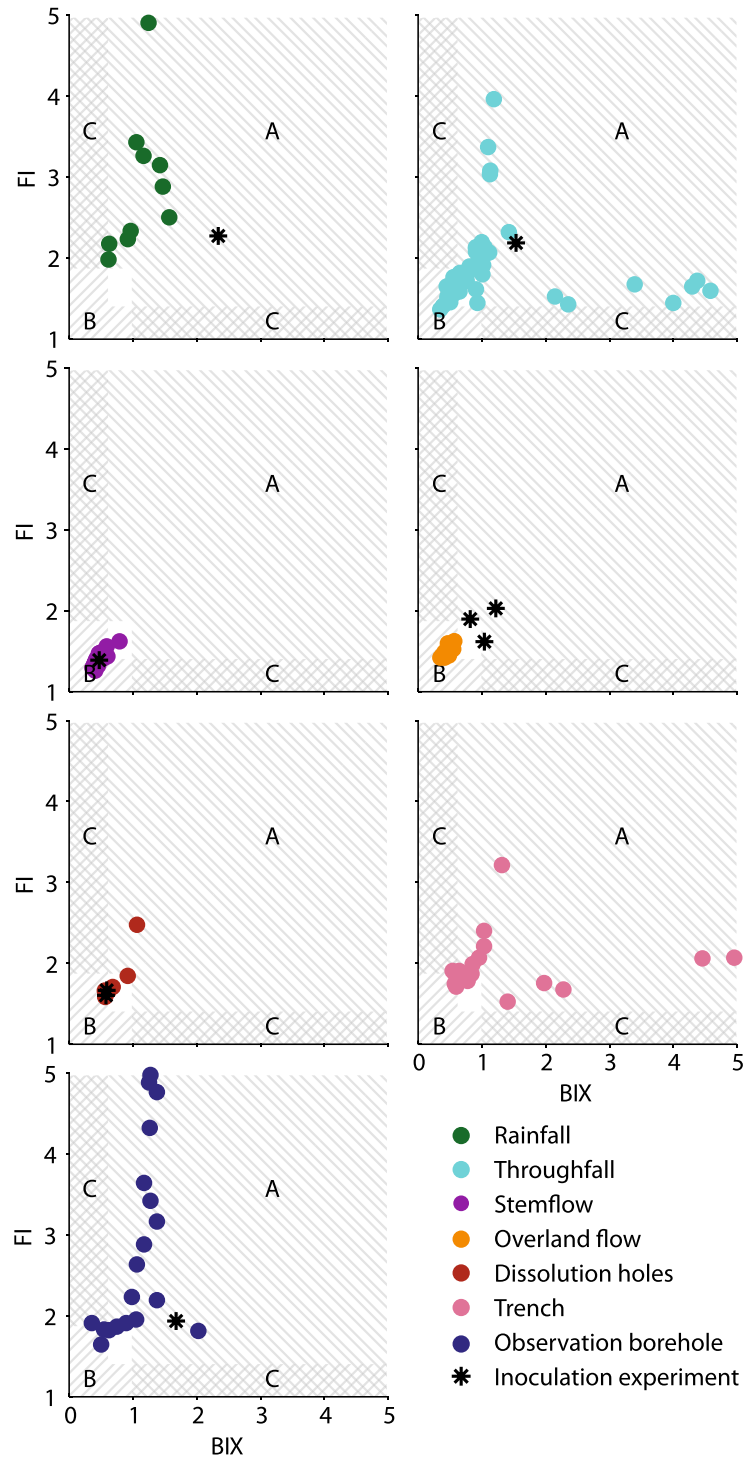

- Throughfall

- Stemflow

- Overland flow

- Dissolution holes

- Trench

- Observation borehole

* Inoculation experiment

Fig. 9 The FI and BIX index for each water type. The terrestrially sourced organic matter should plot within region A of the graph, FI $<1.4$ and BIX $<0.6$, and the microbial sourced organic matter plot within region B of the graph, FI $>1.9$ and BIX $>0.8$. Where one or both indices fail to provide a conclusive indicator of source, samples plot within region $\mathrm{C}$

inoculant was associated with a higher microbial utilisation of organic carbon (least-square regression $\mathrm{r}^{2}=0.58$, Fig. 10). There was a negative correlation between the BIX of the inoculant water and microbial respiration (least-square regression $r=0.49$, Fig. 10). No other significant relationships between the characteristics of the EEMs of the inoculant waters and their corresponding microbial utilisation of organic carbon were apparent, including the bioavailability, expressed in \% DOC, as shown in Fig. 10.

Modelling carbonate dissolution

The results from the modelling of carbonate dissolution are presented in Table 2. The proportion of DOC consumed during the incubation experiments ranges from 1.4 to $6 \%$ of the original DOC concentrations, for rainfall and throughfall respectively. The estimated rate of porosity generation within $10 \mathrm{~cm}$ below the water table ranged from 0.4 to $1.0 \% \mathrm{kyr}^{-1}$, with the lower estimate based on the effective recharge of $0.34 \mathrm{myr}^{-1}$, and the higher estimate assuming all evapotranspiration occurred after dissolution.

\section{Discussion}

The results of this study demonstrate considerable differences in the concentration and the composition of the DOC of the differing waters types, according to the recharge pathway both above and below the ground surface. DOC concentration is variable but high, most notably in stem flow, but also in waters interacting with detrital organic material at the bedrock surface, whilst that of the shallow aquifer waters is low. These differences in both the concentration and the composition of DOC according to recharge route influence the heterotrophic respiratory response of the groundwater heterotrophic community, with implications for development of the shallow epikarst and limestone dissolution at the water table.

Composition and variability of recharge waters

\section{Rainfall}

The convective rainfall events sampled were extremely localised and storm hydrodynamics highly variable, but most have a low DOC concentration, with no systematic differences in concentration or composition between samples from different times during the wet season. The mean value of $3.8 \mathrm{mg} \mathrm{C} \mathrm{L}^{-1}$ is similar to an earlier estimate from Andros of $1.5 \mathrm{mg} \mathrm{C} \mathrm{L}^{-1}$ based on a small number of samples (Whitaker 1992). Both inorganic and organic components of rainfall are controlled by the reactivity 

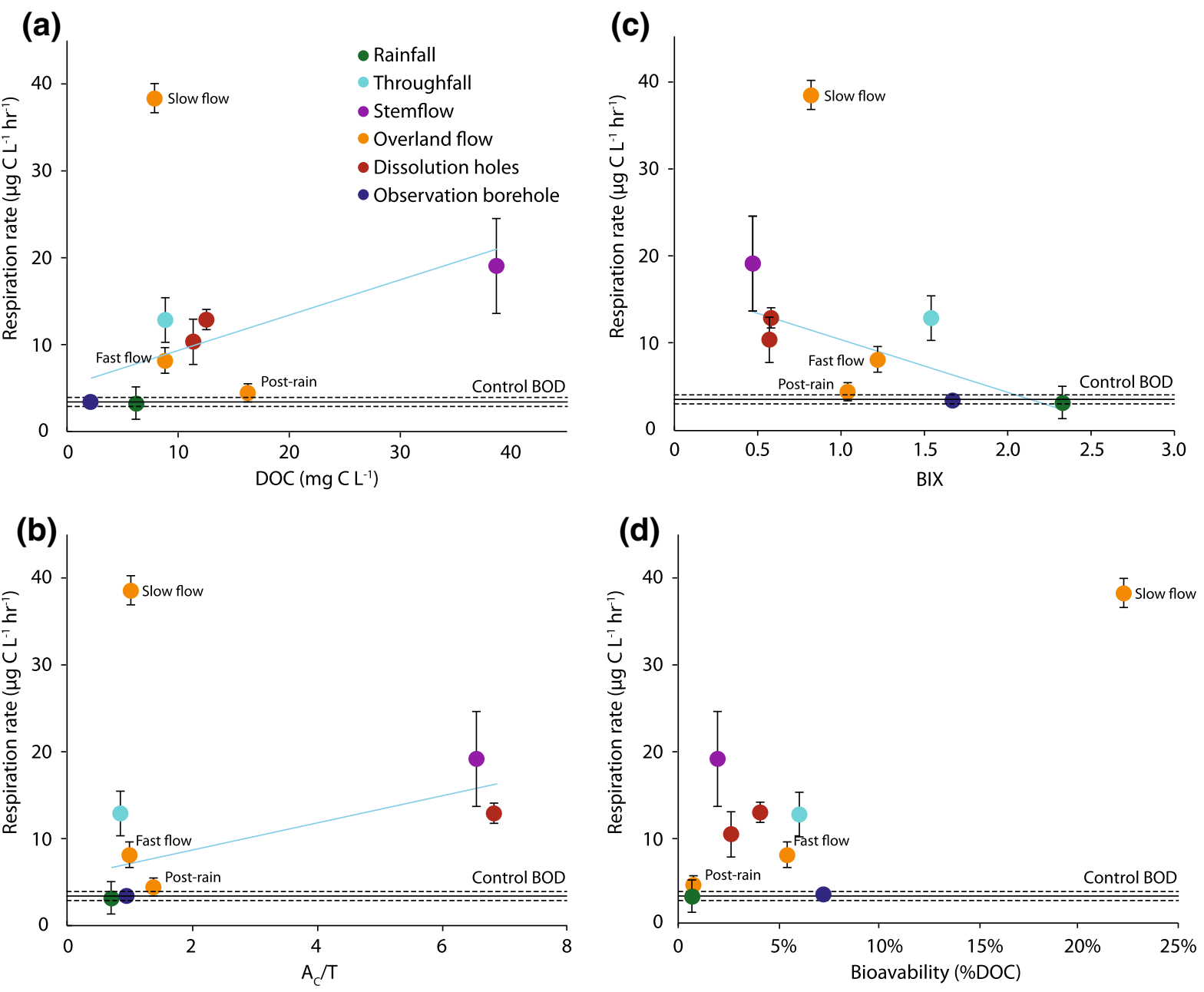

Fig. 10 a Relationship between the respiration rate (mean \pm 1 $\mathrm{SD})$ for the inoculated samples and DOC concentrations of the inoculant. The control respiration rate line is the unfiltered groundwater, with the dashed lines representing $\pm 1 \mathrm{SD}$. The blue

and composition of cloud condensation nuclei, atmospheric aerosols and gases, the sources of which vary both seasonally and spatially, and are heavily influenced by storm hydrodynamics (Pryor et al. 2007). The majority of atmospheric aerosols on North Andros are likely to be derived from either marine or local terrestrial sources, and the variability in the concentration of DOC could depend on meteorological conditions, sample location and the input from these sources.

The EEM data showed that rainfall samples are either dominated by the $\mathrm{C}$ or $\mathrm{T}$ peak (Fig. 8). The $\mathrm{C}$ peak is thought to reflect scavenging, both within and below the clouds, of aerosols from anthropogenic,

linear regression lines show the positive correlation between the BOD and DOC, excluding the slow flow. b Relationship between $\mathrm{A}_{\mathrm{C}} / \mathrm{T}$ and $\mathbf{c}$ BIX of the inoculant waters and respiration rates and d bioavailability of the waters and respiration rates

biomass burning, marine and secondary organic sources (Muller et al. 2008; Zhang et al. 2014). However, the absorption data suggests a markedly low molecular weight and aromaticity, as previously noted by Graber and Rudich (2006).

Previous fluorescence studies of rain DOC composition indicate the ubiquitous presence and common dominance of tryptophan-like fluorescence (Muller et al. 2008; Salve et al. 2012; Santos et al. 2012; Zhang et al. 2014). As with the humic substances, tryptophanlike material is thought to be incorporated during cloud formation due to the presence of proteinaceous and biogenic matter in cloud waters (Muller et al. 2008). Atmospheric sources include bacteria, yeast, 
Table 2 Calculated rate of dissolutional porosity generation driven by respiration of DOC in different types of recharge water

\begin{tabular}{llll}
\hline & $\begin{array}{l}\text { \% DOC } \\
\text { consumed } \\
\text { during } \\
\text { incubant }\end{array}$ & $\begin{array}{l}\text { Low rate of } \\
\text { dissolution } \\
\left(\% \mathrm{kyr}^{-1}\right)\end{array}$ & $\begin{array}{l}\text { High rate of } \\
\text { dissolution } \\
\left(\% \mathrm{kyr}^{-1}\right)\end{array}$ \\
\hline Rainfall & 1.4 & 0.01 & 0.02 \\
Throughfall & 6.0 & 0.11 & 0.30 \\
Stemflow & 1.9 & 0.03 & 0.09 \\
$\begin{array}{l}\text { Overland flow } \\
\text { Dissolution hole }\end{array}$ & 2.1 & 0.14 & 0.39 \\
$\quad 3.4$ & 0.08 & 0.21 \\
$\quad$ water & & 0.37 & 1.02 \\
\hline
\end{tabular}

spores and pollen (Milne and Zika 1993; Determann et al. 1996; Muller et al. 2008). The presence of tryptophan-like material, along with relatively high BIX values $(<0.8)$, has previously been used to infer a significant microbial-origin for atmospheric components within the rainfall (Salve et al. 2012; Zhang et al. 2014).

The variation in the composition of the EEMs between rainfall samples and the relative dominance of $\mathrm{C}$ or $\mathrm{T}$ peaks could be related to storm dynamics. Tryptophan-like material is not reported to be influenced by climatic factors (Muller et al. 2008), however, the humic-like material can reflect the source and type of rainfall event which therefore affects the relative magnitude of $\mathrm{C}$ and $\mathrm{T}$ peaks (Cottrell et al. 2013; Zhang et al. 2014). Muller et al. (2008) noted that high content of humic material is associated with tropical continental convective storms and localised thunderstorms, such as those which contribute most of the rainfall on North Andros. The majority of the sampled rainfall events on North Andros represent localised convective thunderstorms, albeit it heavily influenced by the local marine environment. Thunderstorms promote vertical mixing in the atmosphere, where the intense sunlight and high ozone levels may contribute to the formation of organic acids (Avery et al. 1991).

\section{Throughfall}

As rainfall is the pre-cursor to both throughfall and stemflow, the variability in organic carbon in rainfall will be transmitted down the flow path (Levia and
Frost 2006). DOC concentrations of throughfall are marginally higher than those of rainfall, suggesting additional source(s) of organic carbon. This may be soluble terrestrial- and/or microbial-derived organic matter from the foliage, dry deposition and components leached from the canopy (Ciglasch et al. 2004 and references therein). The composition of the throughfall is also more variable than that of the rainfall samples (for example the spread in $\mathrm{C} / \mathrm{A}_{\mathrm{C}}$ and $\mathrm{C} / \mathrm{T}$ in Fig. 8). Some samples exhibit similar low molecular weights and aromaticity to rainfall, with a similarly high BIX and a high or inconclusive FI index, suggesting organic matter of microbial origin. The samples with higher aromaticity and molecular weight are associated with low BIX and FI values, more similar to the stemflow samples, suggesting more interaction during passage through the canopy. The EEMs, despite being dominated by humic-like material, are more similar to stemflow than to rainfall, with a higher fluorescence intensity of peak $A_{C}$ rather than peak $C$. This suggests a common terrestrial source of organic matter, potentially from material leached from the trees. However, the molecular mass of these samples is lower than that of the stemflow, perhaps because the terrestrial leached material is from the foliage, rather than the bark, which generally has a lighter molecular mass (Levia et al. 2012).

Differing extent of interaction between the rainfall and canopy may account for variability in both concentration and composition of the organic matter in these samples. Those with limited interactions with the foliage resemble the precursor rainfall, whereas increased interaction with the canopy would incorporate organic matter from dry deposition and/or leached material from the plant (Levia and Frost 2006). Both these processes could contribute either terrestrially sourced or microbially altered organic matter (Ciglasch et al. 2004), contributing to the variability observed in the throughfall samples.

A number of other factors influence the rainfall/canopy interactions, including the canopy structure and climate, and could contribute to the variable nature of the throughfall samples. Although the pine forest is predominantly a monoculture, the density of canopy cover is heterogeneous and in many locations sparse. The low leaf surface area, can limit both the availability of dry deposition and also the contact between the rainfall/canopy (Levia and Frost 2006). Dry deposition, comprising dust and degraded 
biological material, accumulates between rainfall events (Levia and Frost 2006; Ciglasch et al. 2004). During the wet season on North Andros there is a rapid succession of storm events, limiting the accumulation of this material.

\section{Stemflow}

The stemflow samples had both the highest and the most variable DOC concentration, likely accounted for by the leaching of organic matter from the tree boles (Ciglasch et al. 2004) and the storm hydrodynamics respectively. However, in contrast to the throughfall, the absorption and fluorescence data have a very low variance, a consistent homogeneous signature of the organic carbon source. The DOM has the highest molecular weight of all the sample types, along with a high level of aromaticity. The fluorescence data indicates the source of the organic matter is terrestrial. The EEMs are dominated by the two humic-like peaks (with a clear $A_{C}$ peak and shouldering $\mathrm{C}$ peak) and the $\mathrm{T}$ is minimal or absent (example shown in Fig. 7). Both the FI and BIX values are low. The composition of the stemflow organic matter, high molecular weight and aromaticity, along with prevalence of humic-like substances, conform to previous studies (Guggenberger et al. 1994; Ciglasch et al. 2004; Levia et al. 2012) which suggest organic matter is derived from the soluble lignin degradation by-products released from the bark of trees. This gives the samples their strong terrestrial signal.

\section{Overland flow and dissolution hole waters}

Overland flow shares many characteristics with stemflow, with a high DOC concentration, high molecular weight and aromaticity, prevalence of humic-like peaks in the EEMs and low FI and BIX values. However, the EEMs for a number of the overland flow samples do show an increased $\mathrm{T}$ peak compared to the stemflow. Variability in characteristics of overland flow samples is thought to be due to the range of flow paths sampled. Overland flow from the scraped surface feeding the trench has a lower DOC concentration than that running over the natural surface into a cave. The latter also has a higher molecular weight and aromaticity, suggesting terrestrial-derived matter from interaction with the canopy and tree boles of the predominantly coppice vegetation, and patchy organic soil in depressions on the bare rock surface. In contrast overland flow towards the trenches interacts with grass anda discontinuous thin soil, developed on the less weathered surface bedrock leading to a stronger microbial source.

Although much of the overland flow infiltrates via solution channels, water-levels can rise in these after heavy rainfall, whilst deeper dissolution holes, and those in areas where the vadose zone is particularly shallow, are permanently water-filled. The DOC concentration of these waters is lower than that of source stemflow and overland flow, but elevated compared to groundwater sampled in boreholes. A similar contrast between the DOC of dissolution hole waters and groundwaters from observation boreholes was noted by Whitaker (1992), with mean concentrations of 16.1 and $4.4 \mathrm{mg} \mathrm{C} \mathrm{L}^{-1}$ respectively, although the DOC from pumped boreholes was considerably higher (17.3 $\left.\mathrm{mg} \mathrm{C} \mathrm{L}^{-1}\right)$. Although the EEMs indicate that the DOC is terrestrial-derived, the molecular weight and aromaticity is low. The BIX and FI values are more variable than those for the source waters. This shift in characteristics of the organic matter may reflect the more extended residence time of the water within the dissolution holes.

Some of these karst features are perched above the water table, providing temporary surface detention, whilst others expose the top of the freshwater lens. In both cases these surface declivities also tend to accumulate foliage debris, such as pine needles, which is comprised of lighter carbohydrates when compared to the bark-derived lignins (Levia et al. 2012). This could explain the lower molecular weight, and aromaticity, of dissolution hole waters when compared to the stemflow. Furthermore, the longer residence time of these waters within the dissolution holes could lead to increased contribution and organic carbon transformation from microbial sources, indicated by higher BIX and FI values and enhanced T contributions in some of the samples. The increased residence time could also account for the $\mathrm{C} / \mathrm{A}_{\mathrm{C}}$ ratio which indicates older, more humified terrestrial material, compared to the source water.

\section{Groundwater from boreholes and trenches}

Samples from the water table from trenches and boreholes exhibit a homogeneously low concentration of DOC, less even than in rainfall, but a highly 
heterogeneous DOC composition. The molecular weight and aromaticity for both sets of samples are lower than that of stemflow and overland flow, yet higher than the majority of the other water types. These water types are unique in that the absorption spectra at shorter wavelengths are relatively low. This precludes the use of $S_{R}$ values.

Whilst some indicator ratios resemble those for overland flow samples, with some terrestrial-sourced organic matter, most of the BIX values are high suggesting more microbial-derived sources. Overland flow is likely to be the major source of organic matter for the trench waters, explaining the similarity in the BIX, FI and the $\mathrm{C} / \mathrm{A}_{\mathrm{C}}$ and $\mathrm{C} / \mathrm{T}$ ratios for some of the samples. As the trench waters are exposed to the atmosphere they may also receive DOC from other sources, such as direct rainfall and dry deposition. If so, this similarity to throughfall, in terms of common source of organic matter, would account for some of the samples exhibiting a similar elevation in BIX values associated with low FI values.

The groundwater samples are enriched in humiclike material, with high SUVA254 and 8280 values suggesting higher molecular weights and aromaticity. The majority of groundwater samples are distinguished by dominance of the $\mathrm{C}$ peak and a clear associated increase in the FI index. The increase in the $\mathrm{C} / \mathrm{A}_{\mathrm{C}}$ ratio in the bulk of the samples suggests that the humic-like material at the water table comprises more humified, older organic molecules compared to the majority of the samples from the surface. This is similar to results for shallow stagnant cave pools where the microbial decomposition of organic matter transforms it to a more stable refractory form in older waters (Shabarova et al. 2014). The increase in the $\mathrm{C} / \mathrm{A}_{\mathrm{C}}$ ratio may indicate the longer residence time, and thus greater age, of groundwater at the top of the freshwater lens, compared to waters interacting with vegetation, the land surface and vadose zone during rapid recharge.

\section{Microbial response to recharge waters}

The inoculation experiment showed that modification of rainfall by interaction with vegetative and land surfaces and percolation though the vadose zone results in recharge waters that can enhance respiration in the native heterotrophic groundwater microbial community. The degree to which respiration rates are stimulated varied according to the type of recharge water, suggesting that the associated differences in organic matter concentration and/or composition are reflected in differences in bioavailability. Excluding one anomalous overland flow sample, there is a clear correlation between the respiration rate and the concentration of DOC in the samples (Fig. 10). As more organic matter is provided to the microbial community, there is a linear increase in respiration rate.

DOC comprises both labile components, more bioavailable smaller molecules such as carbohydrates and proteins, and refractory components, larger less bioavailable macromolecules such as humic substances (Hur et al. 2009). Our data suggests that the differences in the quantity of the organic matter within the inoculant waters is a determinant of microbial activity, where there is a positive correlation between microbial respiration and the concentration of DOC (excluding one anomalous overland flow sample). On the other hand, whether DOM is of terrestrial or of microbial origin contributes very little to controlling the respiration response. Samples with a higher respiration rate-stemflow, overland flow and natural dissolution hole waters-show EEMs where both the C/ $\mathrm{A}_{\mathrm{C}}$ ratio and $\mathrm{BIX}$ value are low, classifying the organic matter as derived from terrestrial rather than microbial sources. Previous work suggests that humiclike material from terrestrial sources is less likely to be utilised by microbial populations as the material tends to be refractory (Hudson et al. 2008). However, Baker et al. (2000) found that large percentages of DOC derived from soil organic matter, rich in humic and fulvic acids, can be consumed by groundwater heterotrophic communities, suggesting that natural systems respond to relative bioavailability.

Recently, Shabarova et al. (2014) showed a significantly decrease in concentration of humic and fulvic acids in cave pools, over a period of weeks, as a result of microbial activity. Our data demonstrate that fresh organic matter derived from terrestrial plants (e.g. via stemflow and in dissolution holes) is somewhat bioavailable (2-4\% DOC), and the bioavailability of the throughfall and runoff is slightly higher. The interaction between rain and vegetation could therefore be an important mechanism that generates terrestrial labile DOC, which in turn maintains microbial respiration in groundwater. In contrast, input of low DOC water, such as rainfall, does little 
to stimulate respiration in groundwater. These waters characteristically show a dominant $\mathrm{T}_{1}$ peak, interpreted as organic matter derived from microbial activity which is less bioavailable both in this study (approximately $1 \%$ DOC), and in previous work by Cammack et al. (2004).

Implications for carbonate dissolution

The role of microbial respiration in generating $\mathrm{CO}_{2}$ to drive carbonate dissolution and contributing to the development of the subsurface karst features has previously been suggested on North Andros by Whitaker and Smart (2007a, b) and more recently on San Salvador in the southern Bahamas by Gulley et al. (2015). The high permeability and limited thickness of the vadose zone ensure rapid transmission (over hours) of recharge water from the ground surface to the top of the freshwater lens, providing a source of both particulate and dissolved organic carbon (Whitaker 1992). Our study expands on this earlier work, highlighting the contrast between the concentrations and composition of organic matter that characterise different recharge pathways, and specifically the role of interactions with vegetation. It also shows that the organic matter entering the system is for the most part labile, and quantifies the degree to which it can stimulate respiration within the heterotrophic microbial community.

The results (Table 2) from the dissolution calculations suggest a rate of porosity generation through the respiration of the heterotrophic microbial community ranging from 0.4 to $1.0 \% \mathrm{kyr}^{-1}$ distributed over a $10 \mathrm{~cm}$ thick zone at the water table. The higher figure, which is based on evapotranspiration occurring after dissolution, is more likely to be correct given the rapidity of recharge, organic matter oxidation and carbonate dissolution. The most important contributions to this total are from overland flow (38\%) and stemflow (30\%), reflecting their high fraction of total flow and high DOC respectively. Although this estimation does account for the differing rates of respiration based on the type of recharge water it does not factor in how these rates may vary with time. The assumption in the calculation is that the bioavailable DOC would be consumed rapidly and that over time this consumption rate would decrease. Here, "rapidly" is defined as the duration of the incubation experiment $(50 \mathrm{~h})$, and is supported by high rates of consumption during this period. However, because of this assumption the estimated rate of dissolution at the water table is potentially an minimum estimate of the amount of DOC which is consumed by the microbial community.

Heterogeneities in recharge pathways and in the concentration and nature of DOC in different types of recharge waters, imply the resulting distribution of dissolution is likely to be spatially variable over the scale of centimetres to tens of metres. Dissolution will be focussed at the bases of trees, where the effect of concentrated input of DOC from stemflow will augment that of $\mathrm{CO}_{2}$ production from root respiration and the possible addition of organic acids. This creates a positive feedback loop whereby the features act as conduits for stemflow, and its associated labile organic matter, to directly reach the freshwater lens. Similarly, rapid routing of overland flow waters to the water table via dissolutional conduits will lead to concentration of dissolution and enlargement of voids at water table which are not necessarily laterally connected.

\section{Conclusions}

This study is, to our knowledge, the first to characterise differing recharge water DOC concentration and composition in a subtropical carbonate environment and evaluate the response of the heterotrophic microbial groundwater community. Results suggest that the different recharge pathways at the surface have a considerable influence on the concentration of DOC in the waters, with increased interaction with vegetation leading to an increase in DOC. These interactions lead to distinctive terrestrial characteristics, with interaction with the foliage or leaf litter providing lighter molecular weight molecules, and interaction with the bark contributing heavier humic lignin molecules. Once the waters reach the water table, the DOC concentrations decrease and there is a shift in the humic-like fraction of organic matter to more refractory stable form.

The experiments to evaluate the response of the groundwater microbial community to different types of DOC show that the majority of the recharge waters provide compounds which enhance heterotrophic respiration within microbial populations in the water table by up to an order of magnitude, depending on the 
water type. Although increased DOC concentration generally leads to an increase in the respiration response, the bioavailability of the organic matter has an important influence. The terrestrially sourced organic matter was shown to be highly labile and readily metabolised. In contrast, microbial-derived DOC seemed to be more refractory, suggesting prior transformation of the labile material in these samples.

This study has a number of implications for karstification. The rapid recharge to the freshwater lens of labile storm derived organic matter has the capacity to stimulate respiration from the heterotrophic microbial community. Based on measured respiration rates, microbially-mediated carbonate dissolution at the top of the lens could generate porosity within the range of $0.4-1 \% \mathrm{kyr}^{-1}$. However, the distribution of this dissolution at the decimetre to metre scale could be highly heterogeneous in nature reflecting recharge pathways of different input waters.

Acknowledgments The study was funded as part of a NERC PhD studentship (NERC 985173) with additional funding from ExxonMobil, SEPM, and the Bristol Carbonates Consortium. Assistance and guidance was provided by: Dr. G. P. Lis for the Fluorolog-3 spectrofluorometer, Dr. C. Yates for the Cary 60 UV-Vis and Dr. J Telling for the Shimadzu TOC-5000A. A subset of DOC analysis was undertaken by Dr. A. Tappin at the University of Plymouth. The authors would like to thank The Government of The Bahamas for granting permission to undertake the field work on North Andros. Assistance with field work was provided by Didi Ooi, Michael Rudd, Jon Hawkings and Miles Frazer.

Open Access This article is distributed under the terms of the Creative Commons Attribution 4.0 International License (http:// creativecommons.org/licenses/by/4.0/), which permits unrestricted use, distribution, and reproduction in any medium, provided you give appropriate credit to the original author(s) and the source, provide a link to the Creative Commons license, and indicate if changes were made.

\section{References}

Avery GJ, Willey J, Wilson C (1991) Formic and acetic acids in coastal North Carolina rainwater. Environ Sci Technol 25:1875-1880

Baker A, Lamont-Black J (2001) Fluorescence of dissolved organic matter as a natural tracer of ground water. Groundwater 39:745-750

Baker M, Valett H, Dahm C (2000) Organic carbon supply and metabolism in a shallow groundwater ecosystem. Ecology 81:3133-3148

Birdwell JE, Engel AS (2010) Characterization of dissolved organic matter in cave and spring waters using UV-Vis absorbance and fluorescence spectroscopy. Org Geochem 41:270-280

Cammack WKL, Kalff J, Prairie YT, Smith EM (2004) Fluorescent dissolved organic matter in lakes: relationships with heterotrophic metabolism. Limnol Oceanogr 49:2034-2045

Cant R, Weech P (1986) A review of the factors affecting the development of Ghyben-Hertzberg lenses in the Bahamas. J Hydrol 84:333-343

Carew JL, Mylroie JE (1995) Depositional model and stratigraphy for the Quaternary geology of the Bahamas Islands. In: Curran HA, White B (eds) Terrestrial and shallow marine geology of the Bahamas and Bermuda Geological Society of America Special Paper, vol 300. Geological Society of America, Boulder, pp 5-32

Chin Y, Aiken G, O’Loughlin E (1994) Molecular weight, polydispersity, and spectroscopic properties of aquatic humic substances. Environ Sci Technol 28:1853-1858

Ciglasch H, Lilienfein J, Kaiser K, Wilcke W (2004) Dissolved organic matter under native Cerrado and Pinus caribaea plantations in the Brazilian Savanna. Biogeochemistry 67:157-182

Coble PG, Spencer RGM, Baker A, Reynolds DM (2014) Aquatic organic matter fluorescence. In: Coble PG et al (eds) Aquatic organic matter fluorescence. Cambridge University Press, Cambridge, pp 75-122

Cooper KJ (2015) Biogeochemistry of an eogenetic karst island: implications for diagenesis. Dissertation, University of Bristol

Cottrell B, Gonsior M, Isabelle LM, Luo W, Perraud V, McIntire TM, Pankow JF, Schmitt-Kopplin P, Cooper WJ, Simpson AJ (2013) A regional study of the seasonal variation in the molecular composition of rainwater. Atmos Environ 77:588-597

Determann S, Reuter R, Willkomm R (1996) Fluorescent matter in the eastern Atlantic Ocean. Part 2: vertical profiles and relation to water masses. Deep Sea Res 43:345-360

Foos A (1989) Topographic effects on aluminous lateritic soil development, Eleuthera island, Bahamas. In: Proceedings of the 4th symposium on the geology of the Bahamas, pp 137-144

Graber E, Rudich Y (2006) Atmospheric HULIS: how humiclike are they? A comprehensive and critical review. Atmos Chem Phys 6:729-753

Guggenberger G, Zech W, Schulten H (1994) Formation and mobilization pathways of dissolved organic matter: evidence from chemical structural studies of organic matter fractions in acid forest floor solutions. Org Geochem 21:51-66

Gulley JD, Martin JB, Moore PJ, Brown A, Spellman PD, Ezell J (2015) Heterogeneous distributions of $\mathrm{CO}_{2}$ may be more important for dissolution and karstification in coastal eogenetic limestone than mixing dissolution. Earth Surf Proc Land 40:1057-1071

Helms J, Stubbins A, Ritchie J, Minor EC, Kieber DJ, Mopper K (2008) Absorption spectral slopes and slope ratios as indicators of molecular weight, source, and photobleaching of chromophoric dissolved organic matter. Limnol Oceanogr 53:955-969

Henry PWT (1974) The pine forests of the Bahamas. Land Resources Division, Oversea Development Agency, Tolworth Tower, Surrey 
Hudson N, Baker A, Ward D, Reynolds DM, Brunsdon C, Carliell-Marquet C, Browning S (2008) Can fluorescence spectrometry be used as a surrogate for the biochemical oxygen demand (BOD) test in water quality assessment? An example from South West England. Sci Total Environ 391:149-158

Huguet A, Vacher L, Relexans S, Saubusse S, Froidefond JM, Parlanti E (2009) Properties of fluorescent dissolved organic matter in the Gironde Estuary. Org Geochem 40:706-719

Hur J, Park M, Schlautman M (2009) Microbial transformation of dissolved leaf litter organic matter and its effects on selected organic matter operational descriptors. Environ Sci Technol 43:2315-2321

Jin J, Zimmerman AR, Moore PJ, Martin JB (2014) Organic and inorganic carbon dynamics in a karst aquifer: Santa Fe River Sink-Rise system, north Florida, USA. J Geophys Res Biogeosci 119:340-357

Korak JA, Dotson AD, Summers RS, Rosario-Ortiz FL (2014) Critical analysis of commonly used fluorescence metrics to characterize dissolved organic matter. Water Res 49:327-338

Lawaetz AJ, Stedmon CA (2009) Fluorescence intensity calibration using the Raman scatter peak of water. Appl Spectrosc 63:936-940

Levia DF, Frost EE (2003) A review and evaluation of stemflow literature in the hydrologic and biogeochemical cycles of forested and agricultural ecosystems. J Hydrol 274:1-29

Levia DF, Frost EE (2006) Variability of throughfall volume and solute inputs in wooded ecosystems. Prog Phys Geogr 30:605-632

Levia DF, Van Stan JT II, Inamdar SP, Jarvis MT, Mitchell MJ, Mage SM, Mchale PJ (2012) Stemflow and dissolved organic carbon cycling: temporal variability in concentration, flux, and UV-Vis spectral metrics in a temperate broadleaved deciduous forest in the eastern United States. Can J For Res 42:207-216

Little BG, Buckley DK, Jefferiss A, Stark J, Young RN (1973) Land resources of the Commonwealth of the Bahamas, v. 4a Andros Island: Land Resources Divisionof the Oversea Development Agency, Tolworth Tower, Surrey, pp 40-110

Lloyd J, Yu Y, Peach D (1992) The management of groundwater abstraction in islands using trenches: a Bahamian example. In: Study and modelling of saltwater intrusion into aquifers. Proceedings 12th saltwater intrusion meeting, Barcelona, pp 489-503

McKnight DM, Boyer EW, Westerhoff PK, Doran PT, Kulbe T, Andersen DT (2001) Spectrofluorometric characterization of dissolved organic matter for indication of precursor organic material and aromaticity. Limnol Oceanogr 46:38-48

Milne P, Zika R (1993) Amino acid nitrogen in atmospheric aerosols: occurrence, sources and photochemical modification. J Atmos Chem 16:361-398

Muller CL, Baker A, Hutchinson R, Fairchild IJ, Kidd C (2008) Analysis of rainwater dissolved organic carbon compounds using fluorescence spectrophotometry. Atmos Environ 42:8036-8045

Ohno T (2002) Fluorescence inner-filtering correction for determining the humification index of dissolved organic matter. Environ Sci Technol 36:742-746
Pronk M, Goldscheider N, Zopfi J (2009) Microbial communities in karst groundwater and their potential use for biomonitoring. Hydrogeol J 17:37-48

Pryor SC, Spaulding AM, Rauwolf H (2007) Evolution of the concentration of inorganic ions during the initial stages of precipitation events. Water Air Soil Pollut 180:3-10

Salve PR, Lohkare H, Gobre T, Bodhe G, Krupadam RJ, Ramteke DS, Wate SR (2012) Characterization of chromophoric dissolved organic matter (CDOM) in rainwater using fluorescence spectrophotometry. Bull Environ Contam Toxicol 88:215-218

Sanchez M, Ingrouille MJ, Cowan RS, Hamilton FMF (2014) Spatial structure and genetic diversity of natural populations of the Caribbean pine, Pinus caribaea var. bahamensis (Pinaceae), in the Bahaman archipelago. Bot $\mathrm{J}$ Linn Soc 174:359-383

Santos PSM, Duarte RMBO, Duarte AC (2009) Absorption and fluorescence properties of rainwater during the cold season at a town in Western Portugal. J Atmos Chem 62:45-57

Santos PSM, Santos EBH, Duarte AC (2012) First spectroscopic study on the structural features of dissolved organic matter isolated from rainwater in different seasons. Sci Total Environ 426:172-179

Shabarova T, Pernthaler J (2010) Karst pools in subsurface environments: collectors of microbial diversity or temporary residence between habitat types. Environ Microbiol 12:1061-1074

Shabarova T, Villiger J, Morenkov O, Niggemann J, Dittmar T, Pernthaler J (2014) Bacterial community structure and dissolved organic matter in repeatedly flooded subsurface karst water pools. FEMS Microbiol Ecol 89:111-126

Simon KS, Pipan T, Ohno T, Culver DC (2010) Spatial and temporal patterns in abundance and character of dissolved organic matter in two karst aquifers. Fundam Appl Limnol 177:81-92

Smart PL, Whitaker FF (1989) Controls on the rate and distribution of carbonate bedrock dissolution in the Bahamas. In: Proceedings, 4th symposium on the geology of the Bahamas, College of the Finger Lakes Field Study Centre, San Salvador, Bahamas, pp 213-221

Stedmon CA, Bro R (2008) Characterizing dissolved organic matter fluorescence with parallel factor analysis: a tutorial. Limnol Oceanogr Methods 6:572-579

Stedmon C, Markager S (2001) The optics of chromophoric dissolved organic matter (CDOM) in the Greenland Sea: an algorithm for differentiation between marine and terrestrially derived organic. Limnol Oceanogr 46:2087-2093

Stedmon CA, Markager S, Bro R (2003) Tracing dissolved organic matter in aquatic environments using a new approach to fluorescence spectroscopy. Mar Chem 82:239-254

Twardowski MS, Boss E, Sullivan JM, Donaghay PL (2004) Modeling the spectral shape of absorption by chromophoric dissolved organic matter. Mar Chem 89:69-88

U.S. Environmental Protection Agency (2010) Low stress purging and sampling procedure for the collection of groundwater samples from monitoring wells. EQASOPGW 001

Weishaar J, Aiken GR, Bergamaschi BA, Fram MS, Fujii R, Mopper K (2003) Evaluation of specific ultraviolet absorbance as an indicator of the chemical composition and 
reactivity of dissolved organic carbon. Environ Sci Technol 37:4702-4708

Whitaker FF (1992) Hydrology, geochemistry and diagnesis of modern carbonate platforms in the Bahamas. Dissertation, University of Bristol

Whitaker FF (1998) Blue holes of the Bahamas: an overview and introduction to the Andros project. Cave Karst Sci 25:53-56

Whitaker FF, Smart PL (1997a) Hydrogeology of the Bahamian Archipelago. In: Vacher HL, Quinn T (eds) Geology and hydrogeology of carbonate Islands. Elsevier, Amsterdam, pp 183-216

Whitaker FF, Smart PL (1997b) Climatic control of hydraulic conductivity of Bahamian limestones. Groundwater 35:859-868

Whitaker FF, Smart PL (2000) Characterising scale-dependence of hydraulic conductivity in carbonates: evidence from the Bahamas. J Geochem Explor 69:133-137

Whitaker FF, Smart PL (2007a) Geochemistry of meteoric diagenesis in carbonate islands of the northern Bahamas: 1. Evidence from field studies. Hydrol Process 21:949-966
Whitaker FF, Smart PL (2007b) Geochemistry of meteoric diagenesis in carbonate islands of the northern Bahamas: 2 . Geochemical modelling and budgeting of diagenesis. Hydrol Process 21:967-982

Wilhartitz IC, Kirschner AKT, Stadler H, Herndl GJ, Dietzel M, Latal C, Mach RL, Farnleitner AH (2009) Heterotrophic prokaryotic production in ultraoligotrophic alpine karst aquifers and ecological implications. FEMS Microbiol Ecol 68:287-299

Zhang YL, Qin BQ, Ma RH, Zhu GW, Zhang L, Chen WM (2005) Chromophoric dissolved organic matter absorption characteristics with relation to fluorescence in typical macrophyte, algae lake zones of Lake Taihu. Huan Jing Ke Xue 26:142-147

Zhang Y, Gao G, Shi K, Niu C, Zhou Y, Qin B, Liu X (2014) Absorption and fluorescence characteristics of rainwater CDOM and contribution to Lake Taihu, China. Atmos Environ 98:483-491 